Article

\title{
Investigating the Effects of Se Solid Phase Substitution in Jarosite Minerals Influenced by Bacterial Reductive Dissolution
}

\author{
Rachel E. Franzblau, Nadine Loick and Christopher G. Weisener * \\ Great Lakes Institute for Environmental Research, University of Windsor, 401 Sunset Avenue, \\ Windsor, ON N9B 3P4, Canada; E-Mails: franzbl@uwindsor.ca (R.F.); \\ nadine.loick@rothamsted.ac.uk (N.L.) \\ * Author to whom correspondence should be addressed; E-Mail: weisener@uwindsor.ca; \\ Tel.: +1-519-253-3000 (ext. 3753); Fax: +1-519-971-3616.
}

Received: 17 October 2013; in revised form: 8 January 2014 / Accepted: 15 January 2014 / Published: 22 January 2014

\begin{abstract}
Jarosite minerals $\left(\mathrm{AB}_{3}\left(\mathrm{TO}_{4}\right)_{2}(\mathrm{OH})_{6}\right)$ are iron hydroxysulfate minerals that can readily incorporate trace metals into their mineral structure. A range of metals can be incorporated into the jarosite structure, including oxyanions such as selenate $\left(\mathrm{SeO}_{4}{ }^{2-}\right)$. Selenium is a micronutrient, but is toxic in relatively low doses. Selenium is present in aqueous systems in its two oxyanion forms: selenate and selenite $\left(\mathrm{SeO}_{3}{ }^{2-}\right)$. The tetrahedral sulfate coordination site can be completely substituted for selenate in jarosite minerals $\left(\mathrm{NaFe}_{3}\left(\mathrm{SO}_{4}\right)_{x}\left(\mathrm{SeO}_{4}\right)_{2-x}(\mathrm{OH})_{6}\right)$. Bacteria have been observed to reduce Se oxyanions to both more reduced forms and insoluble elemental Se. This is a pathway for selenium immobilization at contaminated sites. This experiment investigates the reductive dissolution of two Se-jarosites (solid substitution containing high and low selenium concentrations) in the presence of Shewanella putrefaciens CN32. It was observed that both $\mathrm{Fe}(\mathrm{III})$ and selenate were metabolically reduced and released into solution through jarosite dissolution. Selenate was also found to be incorporated intracellularly and reduced to particulate Se which was released upon cell lysis. Compared to the abiotic samples, enhanced dissolution was found with both the live and dead bacteria treatments.
\end{abstract}

Keywords: jarosite; microbial dissolution; selenium; synchrotron; metals; geomicrobiology; mineral; Shewanella putrefaciens CN32; anaerobic environments 


\section{Introduction}

Soils and sediments serve as an important interface between the biosphere and hydrosphere and can represent a potential sink for metals [1]. Human activities such as mining can lead to the atmospheric exposure of sulfidic soils and sulfide bearing waste rock [2]. These geochemical environments contain reduced forms of iron and sulfur minerals such as pyrite [3]. Soils controlled by iron and sulfur redox chemistry are typically characterized by low pore water $\mathrm{pH}$, and soils containing significant jarosite and/or trace metal loads are often referred to as acid sulfate soils [4,5].

Jarosites $\left(\mathrm{AB}_{3}\left(\mathrm{TO}_{4}\right)_{2}(\mathrm{OH})_{6}\right)$ are iron hydroxysulfate minerals and trace metal scavengers. Jarosites can incorporate a variety of metal(loid)s into the $\mathrm{A}\left(\mathrm{Na}^{+}, \mathrm{K}^{+}, \mathrm{Ag}^{+}, \mathrm{Tl}^{+}, \mathrm{Pb}^{2+}, \mathrm{H}_{3} \mathrm{O}^{+}\right), \mathrm{B}\left(\mathrm{Fe}^{3+}\right)$, and $\mathrm{T}$ $\left(\mathrm{SO}_{4}{ }^{2-}, \mathrm{AsO}_{4}{ }^{2-}, \mathrm{SeO}_{4}{ }^{2-}\right)$ sites [6-9]. Prior work has focused on substitution into the $\mathrm{A}$ and $\mathrm{B}$ sites with some work looking at arsenate substitution into the $\mathrm{T}$ site in conjunction with A site substitution of $\mathrm{Pb}^{2+}[7,8,10]$. However, there have been few prior studies which focus on solid substitution of jarosite minerals in natural environments. This is a concern since the potential for metal(loid) ions to be released and remobilized poses an environmental health risk. During pyrite formation and diagenesis, trace metals such as arsenic (As) and selenium (Se) have been shown to isomorphically replace sulfide in the pyrite lattice $[11,12]$. The subsequent oxidation of this material can serve as a potential source of both Se and As in aqueous systems [2,13].

In aqueous environments $\mathrm{Se}$ forms selenide $\left(\mathrm{Se}^{2-}\right)$ or occurs as two oxyanion species, selenate $\left(\mathrm{Se}^{(\mathrm{VI})} \mathrm{O}_{4}{ }^{2-}\right)$ and selenite $\left(\mathrm{Se}^{(\mathrm{IV})} \mathrm{O}_{3}{ }^{2-}\right)$, which are often associated with iron oxides. The concentration of each Se species depends on the local redox environment [14]. Selenate adsorbs less strongly than selenite and is therefore considered the predominant species susceptible to biotransformation in the environment [15].

Selenium minerals have been reported in arid regions associated with sulfate salts and mine waste [16]. Selenium is able to substitute for sulfur (S) in a variety of minerals as both elements have similar electronic structures [17]. In the case of jarosite, selenium can undergo complete solid phase substitution with selenate replacing the sulfate anion in this mineral's structure [11].

Selenium (Se) is an essential micronutrient present in enzymes such as glutathione peroxidase, which protects cells from damage due to oxidation [18,19]. However, at elevated concentrations, Se is toxic to most biota. Its potential to replace sulfur in amino acids or proteins can alter protein function and interfere with biochemical processes [20,21]. It has also been hypothesized that Se may cause damage to DNA through the production of free radicals [22]. Selenate and selenite can be microbially reduced to elemental selenium $\left(\mathrm{Se}^{0}\right)$ and thereby effectively removed from solution [23-27]. Several bacteria, such as Enterobacter cloacea, Desulfomicrobium norvegicum, Pseudomonas spp., Rhodospirillum rubrum, Shewanella oneidensis, Thauera selenatis and Bacillus spp., isolated from environments both with and without Se contamination, have been shown to be able to reduce Se metabolically [25,28-33]. Selenium tolerant bacteria have the ability to reduce selenium species in part due to their similarity to sulfur based compounds [34]. In regions where selenium contamination is prevalent, the biological reduction of selenate and/or selenite to $\mathrm{Se}^{0}$ has been proposed as a remediation mechanism [15,34]. To better understand potential Se sources and sinks in anaerobic environments, the limitations of Se bioremediation in reducing environments must be considered. The microbial dissolution of Se-containing minerals and its subsequent sequestration as $\mathrm{Se}^{0}$ must be 
assessed. It is hypothesized in this study that a high Se jarosite will be more prone to bacterial dissolution compared to a low Se jarosite due to deformation of the crystal lattice which causes the mineral phase to be unstable. In this study, Shewanella putrefaciens CN32, a dissimilatory metal reducing bacterium was grown in a minimal medium with no added Se. Two Se-jarosite minerals were synthesized, with high $(\sim 100 \%$ Se in the $\mathrm{T}$ site) and low ( $\sim 25 \%$ Se in the $\mathrm{T}$ site) Se replacement for sulfur. This study will investigate the reductive dissolution of jarosite as a function of Se phase substitution (high and low percentage of Se-substitution) in the presence of bacteria through quantitative chemical analyses and the comparison of live and dead biomass treatments and abiotic controls.

\section{Results and Discussion}

The experiment consisted of six treatments containing jarosites with either a low $(\mathrm{L})$ or high $(\mathrm{H})$ substitution of Se for S and live (a), dead (d), or no (n) bacteria present. The treatments are referred to as: $\mathrm{La}=23.5 \% \mathrm{Se}$, live bacteria; $\mathrm{Ld}=23.5 \% \mathrm{Se}$, dead bacteria; $\mathrm{Ln}=23.5 \% \mathrm{Se}$, no bacteria; $\mathrm{Ha}=99.2 \% \mathrm{Se}$, live bacteria; $\mathrm{Hd}=99.2 \% \mathrm{Se}$, dead bacteria; $\mathrm{Hn}=99.2 \% \mathrm{Se}$, no bacteria (see also Section 3.3). Further details on the experimental protocols are provided in the materials and methods section.

\subsection{Aqueous Phase Analysis}

\subsubsection{No-Bacteria Controls (Ln and Hn)}

Total aqueous iron $\left(\mathrm{Fe}_{\mathrm{aq}}\right)$ concentrations (determined via inductively coupled plasma optical emission spectrometry (ICP-OES), DL $=0.04 \mu \mathrm{M}$ ) were low in the abiotic control treatments over the entire experiment (Figure 1). The $\mathrm{Fe}_{\mathrm{aq}}$ release rates over the experimental period were marginal for both Ln and Hn (Table 1). Both solutions remained buffered at $\mathrm{pH} 7.4$ during the experiment. Initial Eh values were at $322 \pm 4 \mathrm{mV}$ for $\mathrm{Ln}$ and $416 \pm 48 \mathrm{mV}$ for $\mathrm{Hn}$; during the first $24 \mathrm{~h}$ the Eh decreased significantly to $243 \pm 15 \mathrm{mV}$ (Ln) and $245 \pm 34 \mathrm{mV}(\mathrm{Hn})$. During the remainder of the experiment, the Eh showed a further slow decrease to final values of $\mathrm{Ln}=214 \pm 43 \mathrm{mV}$ and $\mathrm{Hn}=165 \pm 15 \mathrm{mV}$. As jarosite-minerals are inherently unstable under circumneutral conditions, the significant change in Eh was indicative of a rapid mineral dissolution. The low $\mathrm{Fe}_{\mathrm{aq}}$ concentrations support prior investigations on jarosite dissolution as $\mathrm{Fe}(\mathrm{III})$ exhibits very low solubility at circumneutral $\mathrm{pH}[8,35,36]$. The Ferrozine method showed that all $\mathrm{Fe}_{\mathrm{aq}}$ was in the form of $\mathrm{Fe}(\mathrm{II})[37,38]$. Aqueous Se concentrations $\left(\mathrm{Se}_{\mathrm{aq}}\right)(\mathrm{ICP}-\mathrm{OES}, \mathrm{DL}=0.5 \mu \mathrm{M})$ increased slowly over the experiment (Figure 2) with average release rates of $\mathrm{Ln}=1.5 \pm 0.1 \mu \mathrm{M} / \mathrm{h}\left(R^{2}=0.8227\right)$ and $\mathrm{Hn}=1.6 \pm 0.1 \mu \mathrm{M} / \mathrm{h}\left(R^{2}=0.8996\right)($ Table 2$)$ for the entire experiment. Total $\mathrm{Se}_{\mathrm{aq}}$ was comprised of primarily selenate and a minor concentration of selenite $(5.5 \% \pm 0.0 \%)$ for $\mathrm{Ln}$ and $\mathrm{Hn}$ with the ratio of selenate increasing to $99.5 \% \pm 0.0 \%$ (14 days) in both abiotic controls (Figure 3). Although concentrations of total $\mathrm{Se}_{\mathrm{aq}}$ were elevated over the course of the experiment, both the high and low Se substituted jarosites displayed similar dissolution rates. Adsorption to the jarosite surface was assumed to be negligible in this case and was not investigated as part of this study. It should however be considered in future studies as a possible Se sink. 
Figure 1. Aqueous $\mathrm{Fe}(\mathrm{II})\left(\mathrm{Fe}_{\mathrm{aq}}\right)$ concentrations in $\mu \mathrm{M} / \mathrm{g}$ jarosite. $\mathrm{La}=-\bullet, \mathrm{Ha}=--\odot-$, $\mathrm{Ld}=\rightarrow \boldsymbol{T}, \mathrm{Hd}=-\rightarrow-, \mathrm{Ln}=-\square$, and $\mathrm{Hn}=-\neg-$; error bars are standard errors $(n=3)$.

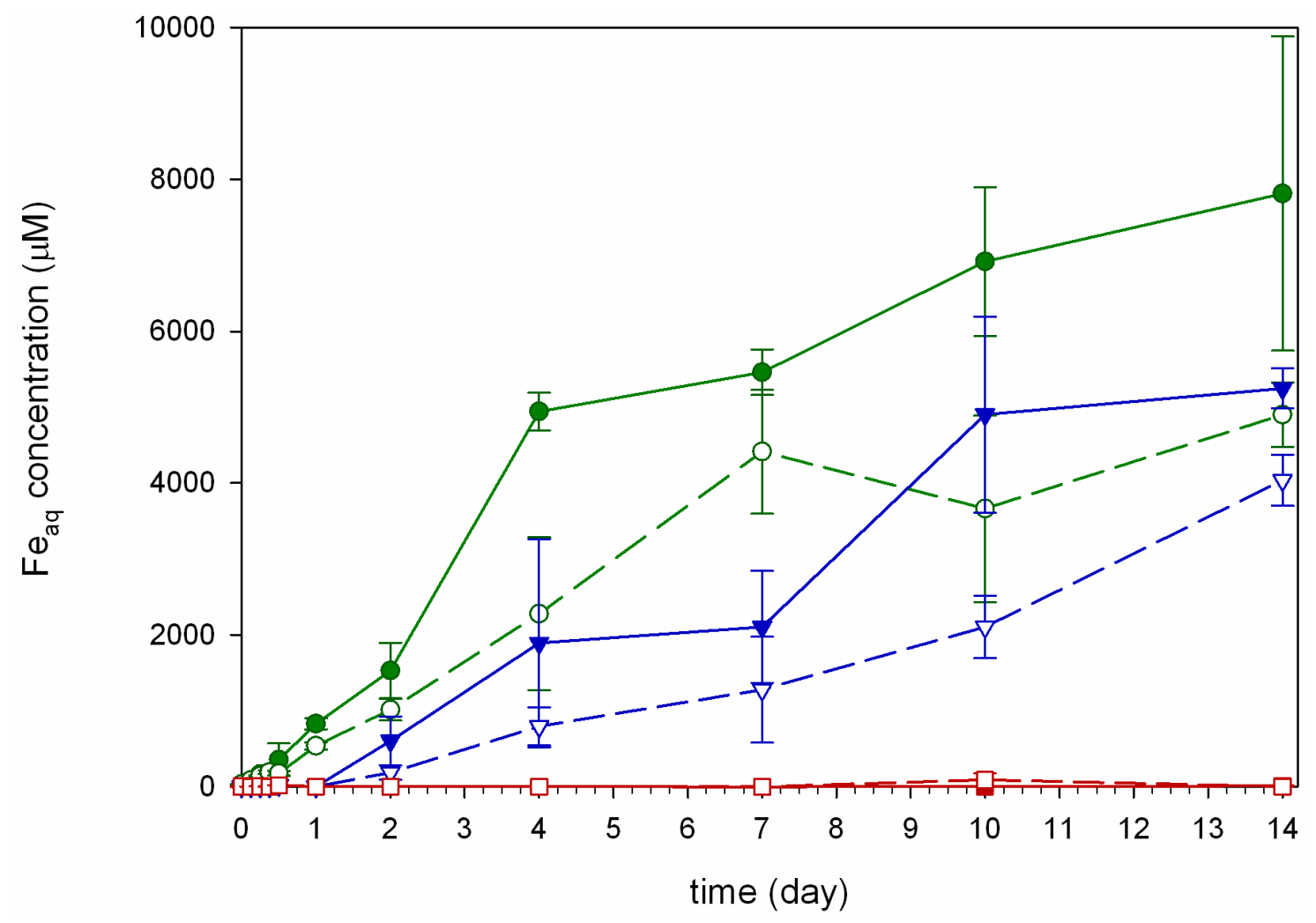

Table 1. Fe(II) release rates in $\mu \mathrm{M} / \mathrm{h}$. Rates of Fe release in $\mu \mathrm{M} / \mathrm{h}$ into solution were determined using inductively coupled plasma optical emission spectrometry (ICP-OES) data are averages \pm standard error for all treatments $(n=3)$. Rates are calculated over the whole experimental period (0-14 days) and separately for $0-24 \mathrm{~h}$ and $24 \mathrm{~h}$ to 7 days, as change in dissolution rates was obvious at $24 \mathrm{~h}$ and 7 days. Values in brackets are $R^{2}$ values derived from a linear trendline used for rate calculations over the stated time period. Negative rates indicate a loss of aqueous Fe (e.g., binding of Fe to the solid phase).

\begin{tabular}{ccccc}
\hline Time-frame treatment & $\mathbf{0 - 2 4} \mathbf{~ h}$ & $\mathbf{2 4} \mathbf{~ h}-\mathbf{7}$ days & $\mathbf{7 - 1 4}$ days & $\mathbf{0 - 1 4}$ days \\
\hline \multirow{2}{*}{$\mathbf{L a}$} & $31.87 \pm 4.52$ & $39.14 \pm 2.06$ & $-8.16 \pm 2.27$ & $20.06 \pm 2.04$ \\
& $(0.7566)$ & $(0.9756)$ & $(0.6497)$ & $(0.7627)$ \\
\cline { 2 - 5 } $\mathbf{H a}$ & $18.63 \pm 1.59$ & $21.22 \pm 1.88$ & $4.31 \pm 2.86$ & $13.83 \pm 0.85$ \\
& $(0.8953)$ & $(0.9409)$ & $(0.3129)$ & $(0.9035)$ \\
\hline Time-frame treatment & $\mathbf{0 - 1 2} \mathbf{~ h}$ & $\mathbf{1 2} \mathbf{h}-\mathbf{7}$ days & $\mathbf{7 - 1 4}$ days & $\mathbf{0 - 1 4}$ days \\
\hline \multirow{2}{*}{ Ld } & $1.29 \pm 0.31$ & $12.82 \pm 2.92$ & $17.58 \pm 7.75$ & $17.66 \pm 1.32$ \\
& $(0.5676)$ & $(0.6364)$ & $(0.4618)$ & $(0.8643)$ \\
\cline { 2 - 5 } Hd & $1.28 \pm 0.31$ & $5.05 \pm 1.49$ & $20.50 \pm 2.82$ & $19.80 \pm 0.72$ \\
& $(0.5619)$ & $(0.5344)$ & $(0.8979)$ & $(0.8893)$ \\
\cline { 2 - 5 } Ln & $1.17 \pm 0.26$ & $-0.07 \pm 0.03$ & $0.06 \pm 0.02$ & $0.01 \pm 0.01$ \\
& $(0.6057)$ & $(0.2957)$ & $(0.4493)$ & $(0.0369)$ \\
\cline { 2 - 5 } Hn & $1.19 \pm 0.36$ & $-0.08 \pm 0.03$ & $-0.04 \pm 0.45$ & $0.09 \pm 0.07$ \\
& $(0.4597)$ & $(0.2779)$ & $(0.0013)$ & $(0.0477)$ \\
\hline
\end{tabular}


Figure 2. Aqueous Se concentration in $\mu \mathrm{M}$ (a) and as \% of total Se (b) comprised of selenate and a negligible amount of selenite in each treatment $. \mathrm{La}=-\bullet, \mathrm{Ha}=-\mathrm{O}_{-}^{-}$, $\mathrm{Ld}=\rightarrow \boldsymbol{\Gamma}, \mathrm{Hd}=-\rightarrow-, \mathrm{Ln}=-\square$, and $\mathrm{Hn}=--\square-$; error bars are standard error $(n=3)$.
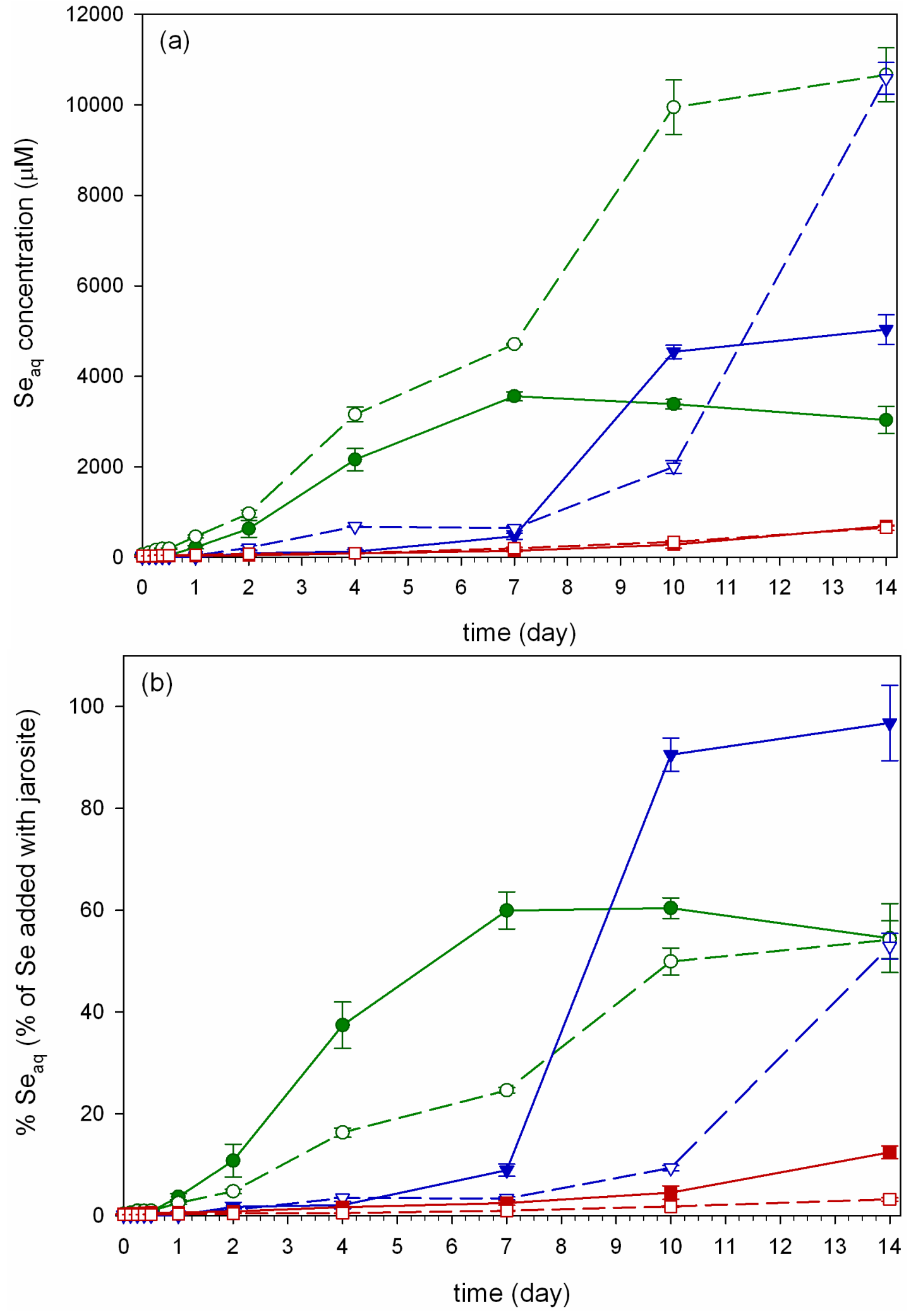
Table 2. Aqueous Se $\left(\mathrm{Se}_{\mathrm{aq}}\right)$ dissolution rates in $\mu \mathrm{M} / \mathrm{h}$ as well as \% of total Se present using ICP-OES data as averages \pm standard error for all treatments $(n=3)$. Rates are calculated over the whole experimental period (0-14 days) and separately for 0-24 h and $24 \mathrm{~h}$ to 7 days, as a change in dissolution rates was obvious at $24 \mathrm{~h}$ and 7 days. Values in brackets are $R^{2}$ values from the linear trendline used to calculate the rates over the given time period. Negative rates indicate the reduction of the aqueous selenium species to more reduced forms (e.g., selenate, selenite) and removal to the solid phase (e.g., elemental selenium).

\begin{tabular}{|c|c|c|c|c|c|c|c|c|}
\hline \multirow{2}{*}{$\begin{array}{c}\text { Time-frame } \\
\text { treatment }\end{array}$} & \multicolumn{4}{|c|}{ Se release rates $\left(\mu M h^{-1}\right)$} & \multicolumn{4}{|c|}{ Se release rates $\left(\% h^{-1}\right)$} \\
\hline & 0-24 h & $24 \mathrm{~h}-7$ days & 7-14 days & 0-14 days & 0-24 h & $24 \mathrm{~h}-7$ days & 7-14 days & 0-14 days \\
\hline $\mathbf{L a}$ & $\begin{array}{c}8.37 \pm 1.14 \\
(0.7718) \\
\end{array}$ & $\begin{array}{c}23.87 \pm 1.59 \\
(0.9576) \\
\end{array}$ & $\begin{array}{c}-3.15 \pm 1.5 \\
(0.3884) \\
\end{array}$ & $\begin{array}{c}11.85 \pm 1.09 \\
(0.7934) \\
\end{array}$ & $\begin{array}{c}0.140 \pm 0.030 \\
(0.8457)\end{array}$ & $\begin{array}{c}0.400 \pm 0.040 \\
(0.9841)\end{array}$ & $\begin{array}{c}-0.034 \pm 0.019 \\
(07587)\end{array}$ & $\begin{array}{c}0.210 \pm 0.030 \\
(0.8305)\end{array}$ \\
\hline На & $\begin{array}{c}16.07 \pm 1.10 \\
(0.9305)\end{array}$ & $\begin{array}{c}44.60 \pm 9.71 \\
(0.6783)\end{array}$ & $\begin{array}{c}23.16 \pm 13.72 \\
(0.2894)\end{array}$ & $\begin{array}{c}33.37 \pm 2.37 \\
(0.8648)\end{array}$ & $\begin{array}{c}0.001 \pm 0.000 \\
(0.5575)\end{array}$ & $\begin{array}{c}0.058 \pm 0.014 \\
(0.9006)\end{array}$ & $\begin{array}{c}0.170 \pm 0.086 \\
(0.7931)\end{array}$ & $\begin{array}{c}0.300 \pm 0.045 \\
(0.8274)\end{array}$ \\
\hline Ld & $\begin{array}{c}0.05 \pm 0.02 \\
(0.3682)\end{array}$ & $\begin{array}{c}11.98 \pm 5.54 \\
(0.3189)\end{array}$ & $\begin{array}{c}16.22 \pm 7.97 \\
(0.372)\end{array}$ & $\begin{array}{c}13.65 \pm 1.37 \\
(0.7621)\end{array}$ & $\begin{array}{c}0.014 \pm 0.003 \\
(0.8452)\end{array}$ & $\begin{array}{c}0.013 \pm 0.001 \\
(0.9898)\end{array}$ & $\begin{array}{c}0.500 \pm 0.300 \\
(0.7337)\end{array}$ & $\begin{array}{c}0.029 \pm 0.004 \\
(0.8457)\end{array}$ \\
\hline Hd & $\begin{array}{c}0.42 \pm 0.13 \\
(0.4104)\end{array}$ & $\begin{array}{c}7.61 \pm 1.99 \\
(0.6183)\end{array}$ & $\begin{array}{c}57.83 \pm 8.15 \\
(0.8936)\end{array}$ & $\begin{array}{c}24.60 \pm 2.63 \\
(0.7503)\end{array}$ & $\begin{array}{c}0.087 \pm 0.010 \\
(0.9452)\end{array}$ & $\begin{array}{c}0.160 \pm 0.019 \\
(0.9733)\end{array}$ & $\begin{array}{c}0.300 \pm 0.100 \\
(0.8948)\end{array}$ & $\begin{array}{c}0.018 \pm 0.010 \\
(0.9714)\end{array}$ \\
\hline Ln & $\begin{array}{c}1.07 \pm 0.09 \\
(0.8986) \\
\end{array}$ & $\begin{array}{c}0.77 \pm 0.07 \\
(0.9294) \\
\end{array}$ & $\begin{array}{c}2.74 \pm 0.71 \\
(0.7143) \\
\end{array}$ & $\begin{array}{c}1.48 \pm 0.13 \\
(0.8227) \\
\end{array}$ & $\begin{array}{c}0.002 \pm 0.001 \\
(0.6252)\end{array}$ & $\begin{array}{c}0.023 \pm 0.009 \\
(0.7703) \\
\end{array}$ & $\begin{array}{c}0.061 \pm 0.015 \\
(0.9410)\end{array}$ & $\begin{array}{c}0.110 \pm 0.025 \\
(0.6937)\end{array}$ \\
\hline Hn & $\begin{array}{c}1.40 \pm 0.18 \\
(0.7965)\end{array}$ & $\begin{array}{c}0.95 \pm 0.16 \\
(0.8045)\end{array}$ & $\begin{array}{c}2.74 \pm 0.35 \\
(0.8989)\end{array}$ & $\begin{array}{c}1.63 \pm 0.10 \\
(0.8996)\end{array}$ & $\begin{array}{c}0.005 \pm 0.001 \\
(0.9493)\end{array}$ & $\begin{array}{c}0.005 \pm 0.001 \\
(0.9573)\end{array}$ & $\begin{array}{c}0.013 \pm 0.001 \\
(0.9964)\end{array}$ & $\begin{array}{c}0.008 \pm 0.001 \\
(0.9363)\end{array}$ \\
\hline
\end{tabular}

Figure 3. Aqueous $\mathrm{Se}(\mathrm{VI})$ concentration in $\%$ of total $\mathrm{Se}_{\mathrm{aq}}$. The remaining $\mathrm{Se}$ was present as $\mathrm{Se}(\mathrm{IV}) . \mathrm{La}=-\bullet, \mathrm{Ha}=--_{-}, \mathrm{Ld}=-\mathbf{T}, \mathrm{Hd}=-\rightarrow-, \mathrm{Ln}=-\bullet$, and $\mathrm{Hn}=--\square-$; error bars are standard error $(n=3)$.

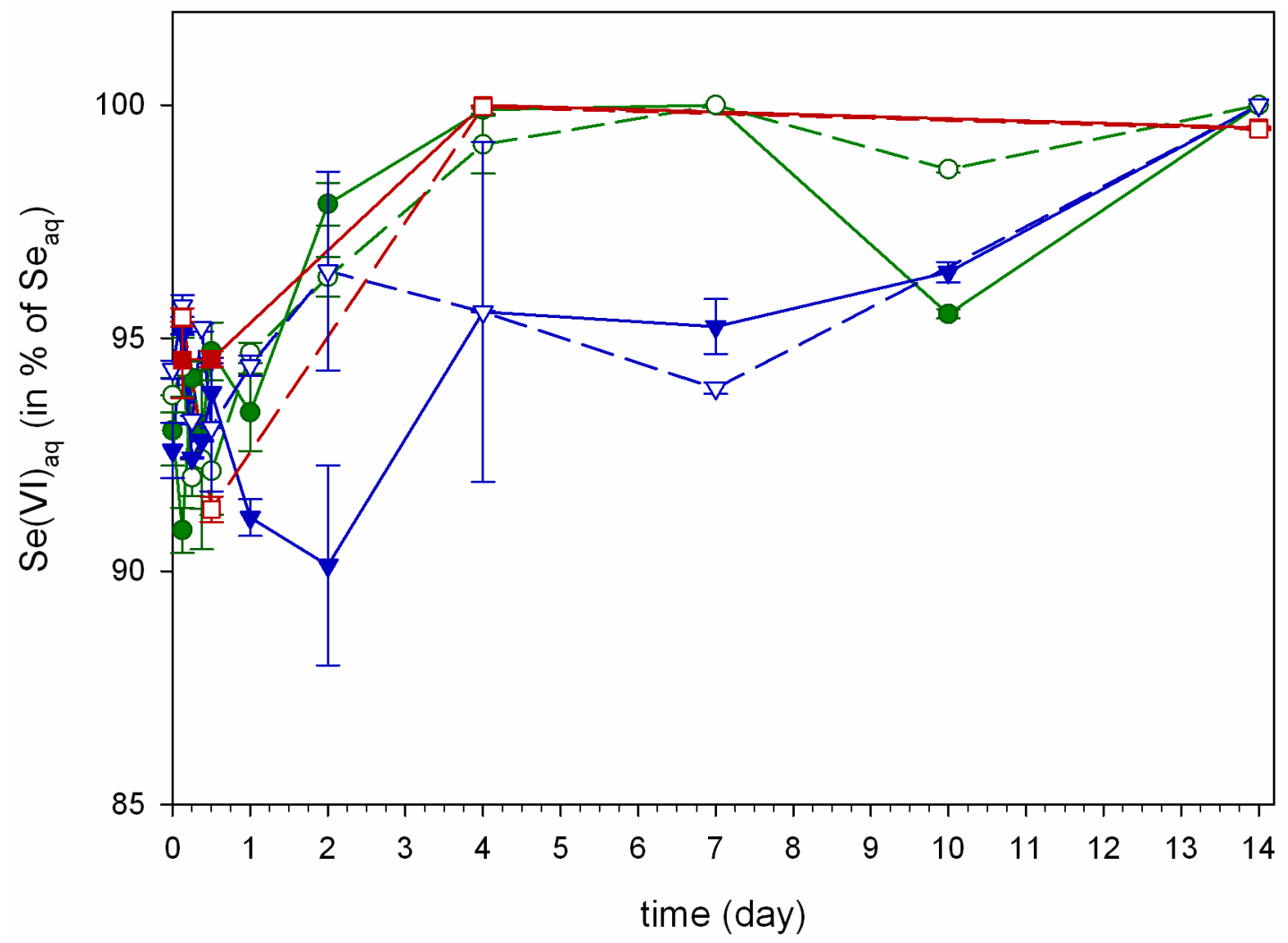




\subsubsection{Dead-Bacteria Treatment ( $\mathrm{Ld}$ and $\mathrm{Hd})$}

In contrast to the abiotic treatments, the dead cell treatments ( $\mathrm{Ld}, \mathrm{Hd})$ showed an increase in the rate of jarosite dissolution. $\mathrm{Fe}_{\mathrm{aq}}$ concentrations increased over time (Figure 1) with release rates over the whole experimental period (14 days) of $17.7 \pm 1.3 \mu \mathrm{M} / \mathrm{h}\left(R^{2}=0.8643\right)$ in $\mathrm{Ld}$ and $19.8 \pm 0.7 \mu \mathrm{M} / \mathrm{h}$ $\left(R^{2}=0.8893\right)$ in Hd (Table 1$)$. For both treatments, the buffering capacity of the minimal media was exhausted at day 2 with final $\mathrm{pH}$ values of $6.6 \pm 0.12(\mathrm{Ld})$ and $6.6 \pm 0.03(\mathrm{Hd})$ (data not shown). Eh values decreased from $325 \pm 37 \mathrm{mV}$ to $-7 \pm 13 \mathrm{mV}(\mathrm{Ld})$ and $314 \pm 5 \mathrm{mV}$ to $-4 \pm 6 \mathrm{mV}$ (Hd), indicating a transition from an oxidizing to a reducing environment. The $\mathrm{Se}_{\mathrm{aq}}$ concentrations increased for both treatments (Figure 2) with higher release rates in the Hd treatment (Table 2). This indicates that dead cells can have a significant impact on Se jarosite dissolution and that the high Se jarosite is more susceptible to dissolution by dead cell material compared to the low Se jarosite as observed in the much higher Se release rates in Hd. This could be caused by increased instability of the high Se jarosite which has a larger $c$ spacing than the low Se jarosite [11]. This would cause the 100\% Se jarosite (Hd) to be more easily dissolved in the presence of bacterial cells. The percentage of selenate released from the jarosites increased in $\mathrm{Ld}$ from $92.6 \% \pm 1.0 \%$ to $100 \% \pm 0.0 \%$ and in $\mathrm{Hd}$ from $94.3 \% \pm 0.3 \%$ to $100 \% \pm 0.0 \%$ with minor concentrations of selenite present at the earlier time points. Additionally, there was no metabolic reduction of selenate in the dead cell samples (Ld, Hd); therefore, all Se released during jarosite dissolution remained in solution. The Ld samples released the greatest percentage of Se into solution indicating complete dissolution of the Se-containing fraction of the jarosite at 14 days (Figure 2). However, further experiments will have to be done to determine why the Ld samples released a significantly higher percentage of Se into solution than the Hd samples. Prior work on selenate adsorption to Shewanella putrefaciens 200R under variable $\mathrm{pH}$, ionic strength, biomass concentration, and initial selenate concentration found that adsorption increased with biomass concentration and decreased with increasing ionic strength and $\mathrm{pH}$ [39]. Therefore, in the current study, little adsorption would have occurred in the abiotic treatments under circumneutral $\mathrm{pH}, 1 \mathrm{~g} / \mathrm{L}$ biomass and high ionic strength. The decrease in $\mathrm{pH}$ and $\mathrm{Eh}$ and corresponding increase in $\mathrm{Fe}_{\mathrm{aq}}$ and $\mathrm{Se}_{\mathrm{aq}}$ concentrations and release rates compared to the abiotic samples suggests that the dead cells enhanced jarosite dissolution rates. In addition, this would suggest that jarosites with high selenate substitution are prone to higher Se release rates resulting in more selenate in solution compared to jarosites with a low selenate substitution. Increased incorporation of selenate into the jarosite structure results in lattice strain as the $c$ parameter increases linearly with Se substitution for S and could be the cause of the observed enhanced dissolution in Hd versus Ld [11].

\subsubsection{Live Bacteria (La and $\mathrm{Ha})$}

The live bacteria treatments $\left(\mathrm{Ha}, \mathrm{La}\right.$ ) displayed the most dissolution with initial $\mathrm{Fe}_{\mathrm{aq}}$ concentrations of around $45 \mu \mathrm{M}$ increasing to final concentrations of $5004.4 \pm 420.0 \mu \mathrm{M}(\mathrm{La})$ and $4167.8 \pm 280.1 \mu \mathrm{M}$ (Ha) (Figure 1). As with the dead bacteria treatments, the buffering capacity of the live bacteria treatments was exhausted after $9 \mathrm{~h}$ with initial $\mathrm{pH}$ values of $\mathrm{La}=7.33 \pm 0.01$ and $\mathrm{Ha}=7.32 \pm 0.01$ decreasing to final $\mathrm{pH}$ values of $\mathrm{La}=6.2 \pm 0.08$ and $\mathrm{Ha}=6.5 \pm 0.05$. The initial Eh values of these treatments were negative $(\mathrm{La}=-94 \pm 18 \mathrm{mV}$ and $\mathrm{Ha}=-80 \pm 27 \mathrm{mV})$ and showed a further decrease 
during the first $6-9 \mathrm{~h}$ to $-238 \pm 10 \mathrm{mV}$ (La) and $-220 \pm 20 \mathrm{mV}$ (Ha) indicating a shift to strongly reducing conditions. After $24 \mathrm{~h}$, the Eh potential of the solution gradually increased to values similar to those measured for treatments Ld and Hd. After four days, no significant difference in Eh could be detected between the live cell and the dead cell treatments. The change in Eh to a higher potential suggests a transition from reducing to oxidizing conditions over the 14 day sampling period. The initial decrease in Eh is a result of bacterial reduction of $\mathrm{Fe}$ (III) and selenate from the jarosites to Fe(II) and $\mathrm{Se}^{0}$. The initial drop in Eh was not observed in the abiotic and dead cell treatments as no metabolic reduction of $\mathrm{Fe}$ (III) or selenate occurred in the absence of live bacteria. $\mathrm{Se}_{\mathrm{aq}}$ concentrations increased steadily 216 fold in $\mathrm{La}$ and 170 fold in $\mathrm{Ha}$ (Figure 2) with three times higher release rates in Ha compared to $\mathrm{La}$ (Table 2). Similar to the other treatments $\mathrm{Se}_{\mathrm{aq}}$ was mainly comprised of selenate, increasing from $93.0 \% \pm 1.3 \%$ to $100 \% \pm 0.0 \%$ in $\mathrm{La}$ and from $93.8 \% \pm 0.6 \%$ to $100 \% \pm 0.0 \%$ in $\mathrm{Ha}$. The high $\mathrm{Fe}_{\mathrm{aq}}$ and $\mathrm{Se}_{\mathrm{aq}}$ concentrations and changes in $\mathrm{pH}$ and $\mathrm{Eh}$ indicate that significant dissolution occurred in the live bacteria samples. Additionally, the $\mathrm{Fe}_{\mathrm{aq}}$ and $\mathrm{Se}_{\mathrm{aq}}$ concentrations were higher in the live bacteria samples than the abiotic control and dead cell samples. These results indicate that the presence of metabolically active bacteria will stimulate Se-jarosite dissolution under reducing conditions through both metabolic activity and non-metabolic interactions between the dead cells and jarosite minerals.

\subsection{Solid Phase Analysis}

\subsubsection{Scanning Electron Microscopy}

The abiotic samples ( $\mathrm{Ln}, \mathrm{Hn}$ ) showed no visible dissolution over the 14 day sampling period. The live bacteria samples ( $\mathrm{La}, \mathrm{Ha}$ ) showed the greatest degree of dissolution. In both the $\mathrm{La}$ and $\mathrm{Ha}$ samples, visible surface dissolution textures (terraces, pits) along with secondary precipitates were visible within two days (Figure 4). The chemical composition of the secondary precipitate was determined using scanning electron microscopy-energy dispersive spectroscopy (SEM-EDS) and transmission electron microscopy-energy dispersive spectroscopy (TEM-EDS) confirming the alteration of the primary jarosite (La: Fe 14.7 at $\%$, O 70.0 at $\%$, Se 2.6 at $\%$, Ha: Fe 14.2 at \%, O 69.8 at $\%$, Se $11.1 \mathrm{at} \%$ ) to a secondary iron oxide phase (Fe 25.9 at\%, O 41.0 at $\%$ ). The secondary mineral phase in $\mathrm{La}$ and $\mathrm{Ha}$ is a result of incongruent dissolution in the presence of bacteria. Similar precipitates were observed previously, and were determined to be schwertmannite $>$ goethite $>\mathrm{Fe}(\mathrm{OH})_{3}$ [8]. Due to the complexities involved in a mixed bacterial mineral system, an accurate mass balance could not be done. Future experiments would be required to address this issue to track adsorption and assess of the composition of the secondary mineral phases, including a combination of targeted extractions of adsorbed species and secondary precipitates. Rietveld phase analysis could be done as well, assuming the phases formed are crystalline and not below detection limit for X-ray diffraction. In the case of this study, an accurate mass balance was not possible due to these uncertainties. From a qualitative perspective, the Ha samples showed evidence of dissolution at earlier time points suggesting enhanced dissolution compared to the La samples as well as an increased instability of the high Se-jarosite phase. Similar observations were made for synthetic arsenate $\left(\mathrm{AsO}_{4}{ }^{2-}\right)$ jarosites which can substitute up to $9.91 \mathrm{wt} \%$ arsenate for sulfate resulting in the distortion of tetrahedral sites and structural weakness in 
nearby octahedral sites [40]. As the experiments progressed, both La and Ha displayed extensive pitting and terracing after four days with the formation of secondary precipitate along the mineral faces. However, as both the high and low Se-phases show a similar degree of dissolution at 14 days, this effect is likely not significant except over short time periods of less than four days. At day 14, none of the original jarosite was apparent; instead a crystal framework of mainly secondary iron oxide precipitate remained. Particles of $\mathrm{Se}^{0}$ were detected via SEM-EDS in both the La and Ha samples but were not observed in either the dead cell or abiotic treatments. These particles were first observed in the $24 \mathrm{~h} \mathrm{La}$ and Ha samples (data not shown) and increased in number as time went on. Their presence in only the treatments containing living bacteria suggests that the occurrence of elemental selenium is directly related to bacterial metabolism [33,41-43]. Previous investigations have observed both intracellular $[42,44,45]$ and extracellular $[46,47]$ Se particles of various sizes and the precipitation mechanisms vary with the bacterial species. A prior study attributed intracellular elemental Se precipitation to a detoxification mechanism as $\mathrm{Se}^{0}$ particles were observed within discrete internal membranes in Bacillus selenitireducens [42].

\subsubsection{Transmission Electron Microscopy}

The cross-sectional information provided by the transmission electron microscopy (TEM) analyses complements the SEM imaging already discussed. In treatment La, alteration of the primary jarosite to a secondary precipitate is apparent (Figures 4 and 5). Based on SEM-EDS and TEM-EDS analyses, the secondary phase consisted of iron oxides which were not specifically identified during this study. The iron oxide secondary precipitate concentration increased with time so that at day 4 a distinct shell surrounded the partially dissolved jarosite in both the La and Ha treatments. After 14 days, the primary mineral phase had undergone complete alteration to secondary iron oxides. Based on the solution data, the Ha samples dissolved more rapidly than the La samples during the initial stages of the experiment and dissolution progressed more slowly from day 7-14.

TEM images of the 0 h, 2 day, 4 day and 14 day time points were collected for both the La and Ha treatments and elemental Se was visibly associated with bacterial cells (Figure 6). Fewer of the $\mathrm{Se}^{0}$ particles were observed in the Ha samples versus the La samples. Intracellular $\mathrm{Se}^{0}$ particles were observed in the La samples at day 2 and day 4 in the Ha samples. This was also confirmed by X-ray absorption near-edge spectroscopy (XANES) analysis, which showed a shift towards the more reduced Se species, including $\mathrm{Se}^{0}$, over time. The delayed appearance of Se particles in Ha could be related to lower cell activity due to higher doses of Se, resulting in potentially increased toxicity to S. putrefaciens. Bacterial activity and survival was estimated by ATP measurements (data not shown). Though not significantly different, Ha samples showed a slightly faster decline in ATP indicating a lower cell activity in those samples (relative luciferase units (RLU) decreased in Ha from $105 \times 10^{6} \mathrm{RLU}(0 \mathrm{~h})$ to $95 \times 10^{6}(3 \mathrm{~h}) \mathrm{RLU}$ and $15 \times 10^{6} \mathrm{RLU}$ (4 days); ATP levels in La decreased from $107 \times 10^{6} \mathrm{RLU}$ to $103 \times 10^{6} \mathrm{RLU}(3 \mathrm{~h})$ and $26 \times 10^{6} \mathrm{RLU}(4$ days)). To further test this, TEM line-scans (Figure 7) were performed to document Se diffusion gradients associated with the high and low Se jarosites. These line scans of bacterial cells in contact with high Se jarosite minerals showed evidence of increased Se concentrations at the bacteria-mineral interface in the Ha experiments. This gradient was not observed in the La treatments. This observation suggests that the bacteria were attempting to prevent the uptake of a 
large amount of Se. This could also be due to Se accumulation at the cell surface which is an alternate potential detoxification mechanism. However, more experiments will have to be done to determine the exact mechanism of Se detoxification used by Shewanella putrefaciens CN32. By comparison, the dead cell samples showed similar dissolution trends with slightly lower rates of dissolution and no evidence of intracellular $\mathrm{Se}^{0}$ was observed. In this case, the presence of organic matter alone appeared to enhance dissolution of these mineral phases but did not contribute to the formation of elemental Se.

Figure 4. Scanning electron microscopy (SEM) images of La and Ha at (a) 0, (b) 2, (c) 4, and (d) 14 days showing the progression of jarosite dissolution along with the evolution of Se particles. Both $\mathrm{La}$ and $\mathrm{Ha}$ show evidence of pitting on terraces and other surface features indicative of surface enhanced dissolution textures after (b) 2 and (c) 4 days. After (d) 14 days, both $\mathrm{Ha}$ and La behave similarly, in both treatments incongruent dissolution yields a new secondary mineral comprised of $\mathrm{Fe}, \mathrm{O}$ and $\mathrm{H}$, note in both experiments the abundance of selenium nanoparticles formed on the surface as a result of bacterial activity. All scale bars denote $10 \mu \mathrm{m}$.

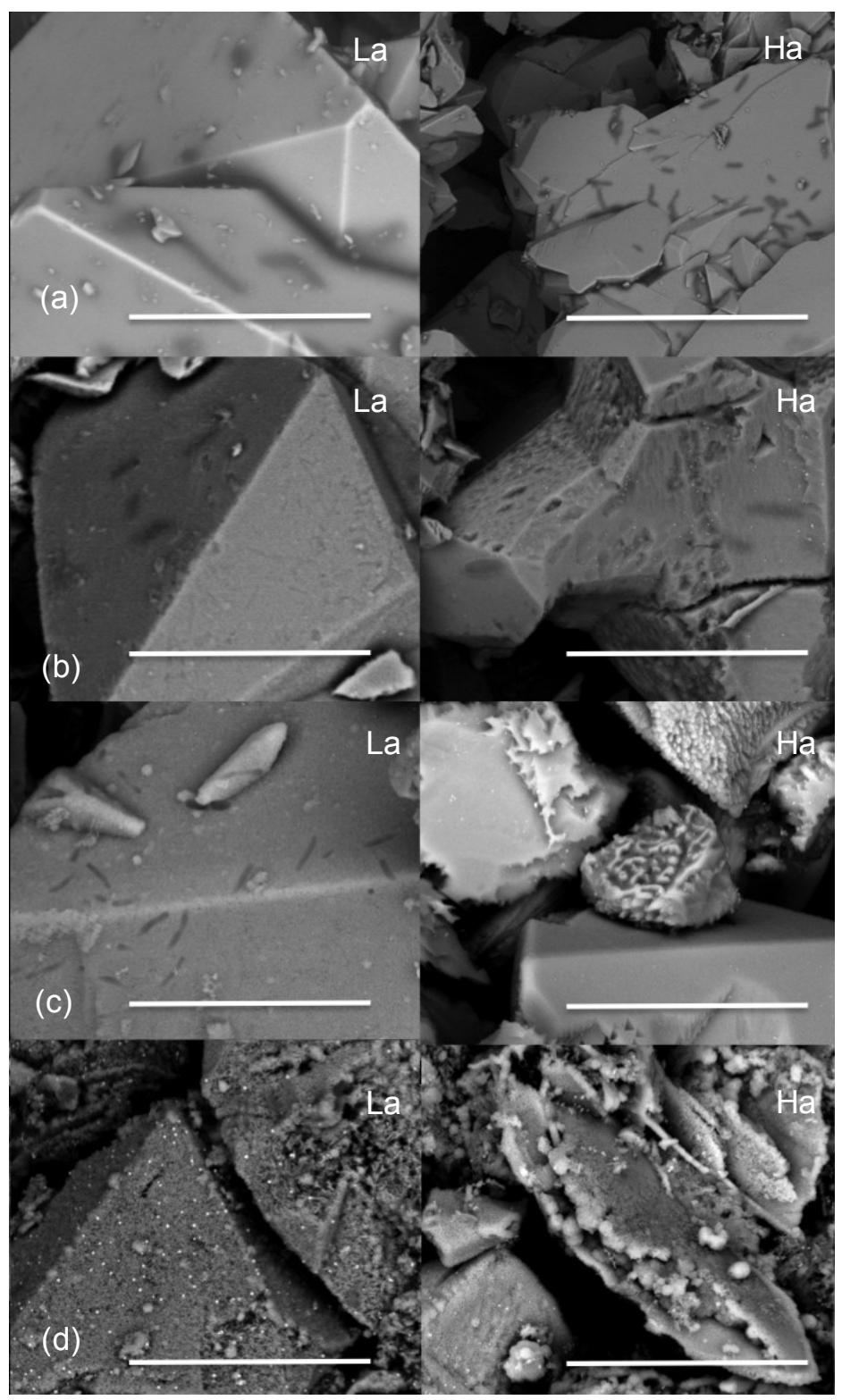


Figure 5. Representative transmission electron microscopy (TEM) images providing a cross sectional overview of La and Ha treatments at (a) 2, (b) 4, and (c) 14 days. Jarosites of both La and Ha show a similar incongruent dissolution pathway resulting in the removal of $\mathrm{Fe}$ and Se leaving a secondary mineral phase comprised of iron oxide shells which began forming after day 2 . This transformation continued progressively until day 14 . In both cases, a secondary mineral product of iron oxide is formed. All scale bars denote $1 \mu \mathrm{m}$.

(a)

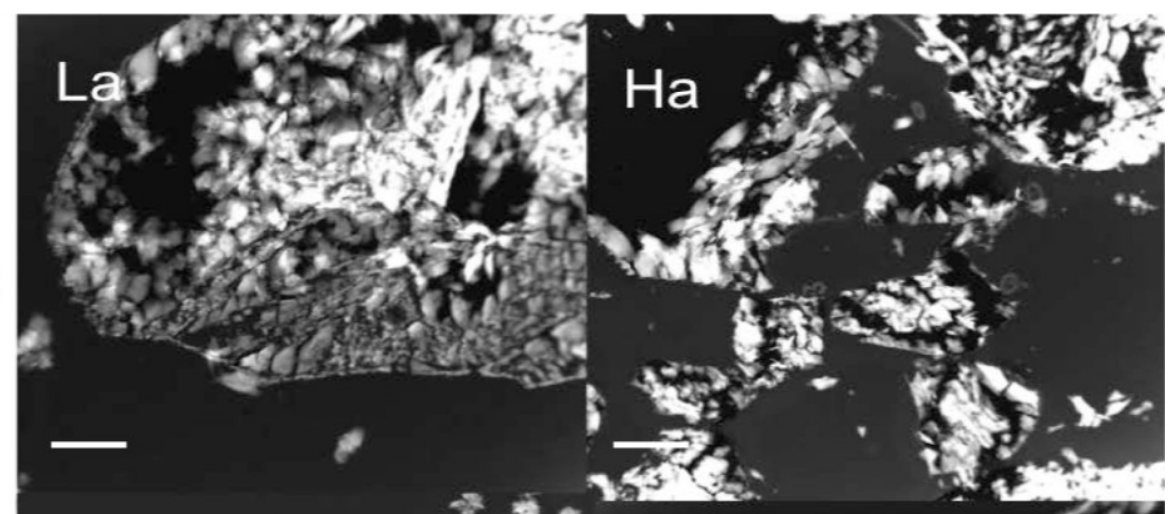

(b)

(c)

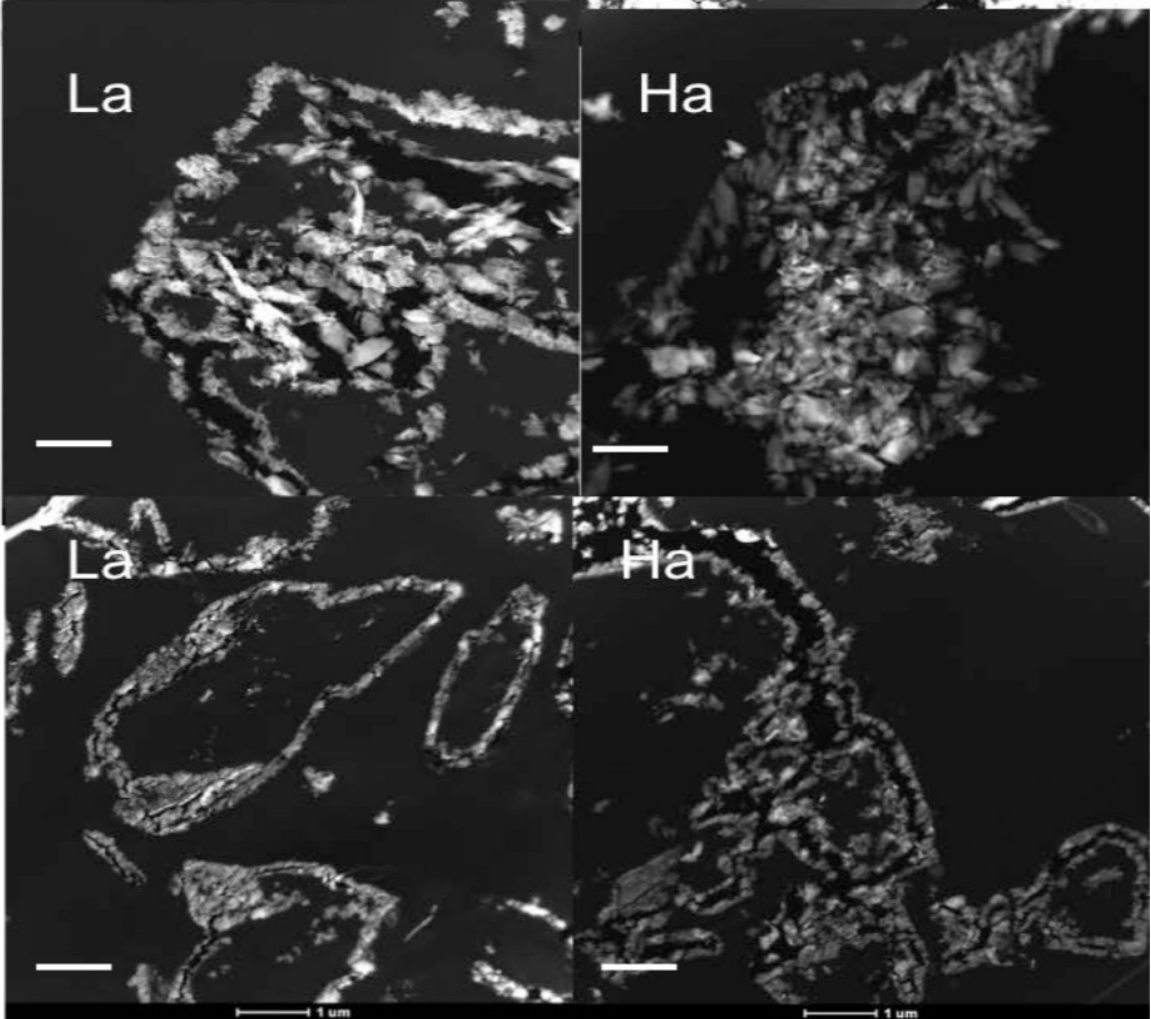


Figure 6. TEM images of bacterial cells and lysed bacterial cells associated with the low dose treatment (La) sampled at day $4(\mathbf{A}, \mathbf{B})$ and day 14 (C,D) The white scale bars denotes $50 \mathrm{~nm}(\mathbf{B}-\mathbf{D})$ and $100 \mathrm{~nm}(\mathbf{A})$. Arrows denote the locations of intra- and extra-cellular $\mathrm{Se}^{0}$ particles.

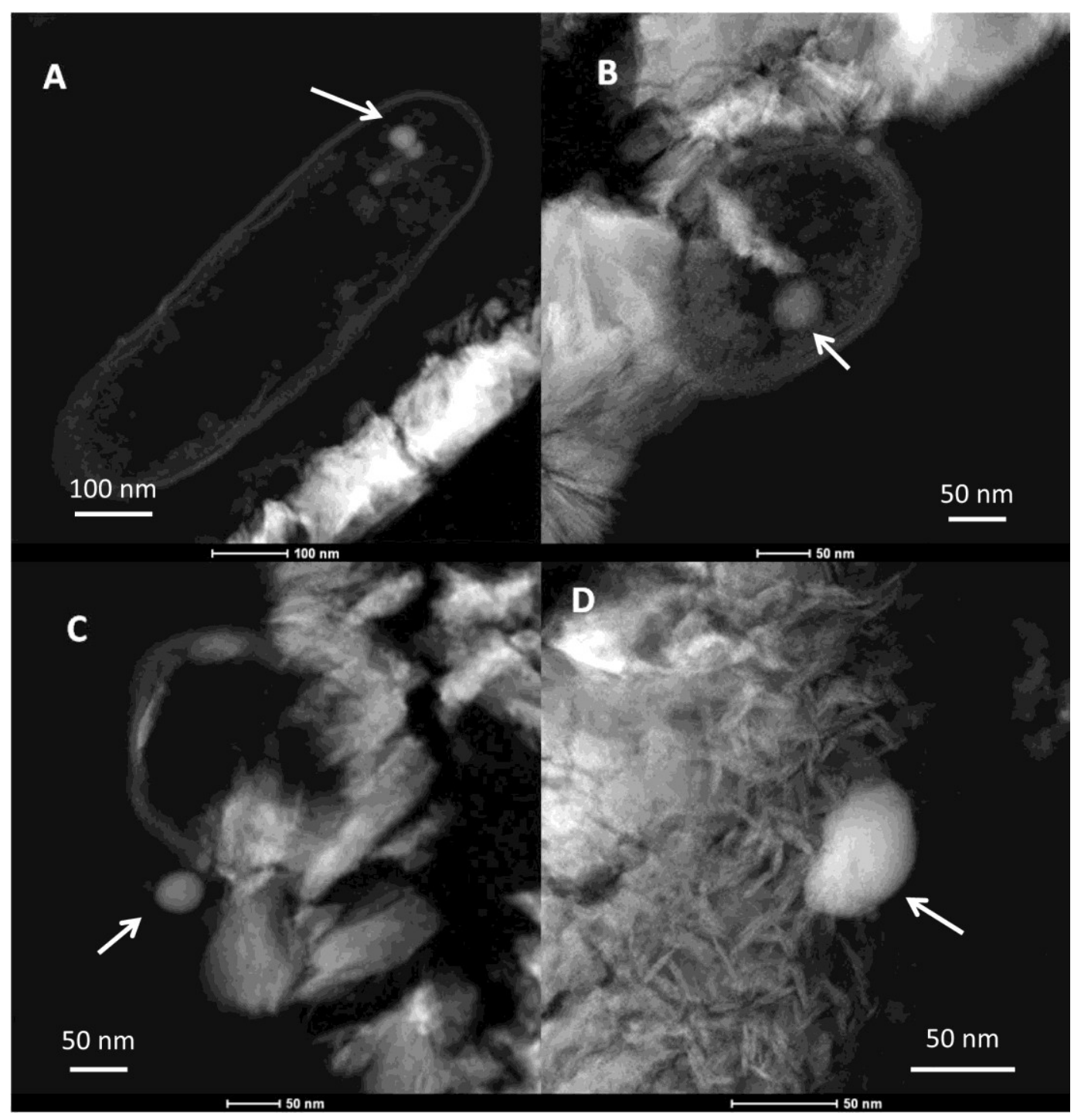

Based on the TEM and SEM analyses of the live bacteria treatments, a pattern of gradual release of Se particles with progressing cell lysis emerged in both La and Ha. Figure 7 illustrates the gradual accumulation and release of Se particles for the time periods analyzed. The micrograph characterizes the fate of the particulate Se observed in the high and low dose jarosite experiments (La and Ha). It should be noted that although Se particles were observed in TEM images for both treatments (La and $\mathrm{Ha}$ ), there appeared to be fewer $\mathrm{Se}^{0}$ particles in Ha based on a qualitative analysis of the sample areas analyzed at day 2. To confirm this assumption, integrated particle identification could be used to provide statistically valid reproducibility; unfortunately this technique was not available at the time of analysis. 
Figure 7. Transmission electron microscopy (TEM) line-scan data of a bacterial cell in contact with the high selenium jarosite (4 days, Ha). Line scans were performed moving across the mineral section into the bacterial cell. The inset plot summarizes the chemical information collected from the white circled region (carbon (red), iron (blue), selenium (purple), oxygen (green)) along the line scan. The steep increase in carbon concentration marks the edge of the cell. The line-scan reveals a Se concentration gradient peaking at the cell-mineral interface with no intra- or extra-cellular Se particles visible.

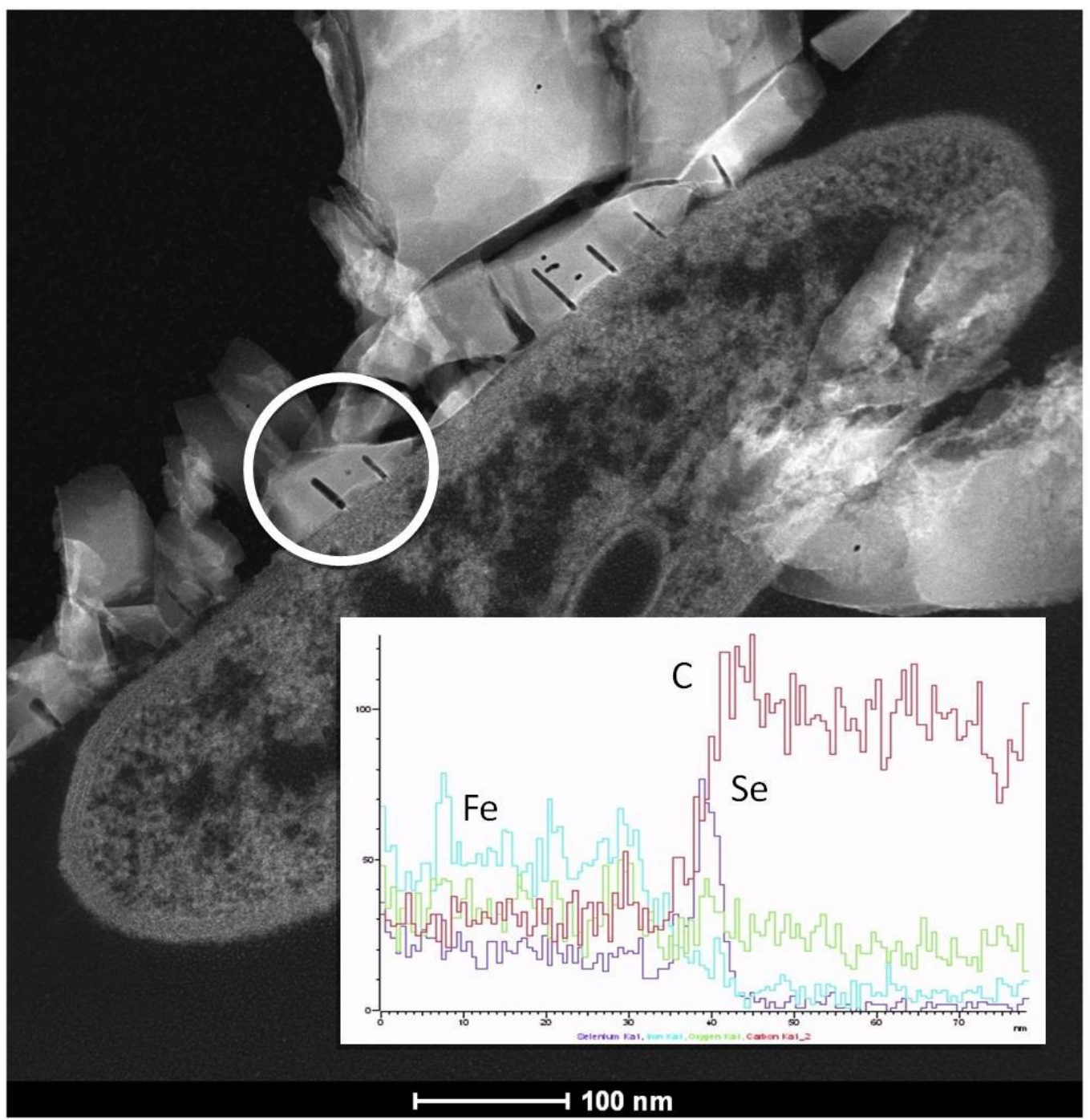

\subsubsection{Selenium Speciation in the Solid Phase}

Determining the oxidation states of Se is important to improve our understanding of Se mobility. Synchrotron based X-ray absorption near edge structure (XANES) analysis (Figure 8) was used to determine solid phase changes in selenium oxidation states over the course of the experiment. XANES spectra showed a gradual shift in Se oxidation state in the live cell samples compared to the abiotic and dead cell samples. Figure 8 shows a comparison of the XANES derivative spectra collected for the experimental treatments. Between 0 and $24 \mathrm{~h}$, the spectra show no change in Se oxidation state in the solid phase; in all cases, Se was mainly present as Se(VI). During the course of the experiment, a "shoulder" of lower energy appeared in the spectra for both the live and dead cell treatments. This 
indicates a shift in the Se K-edge to lower energies and therefore the presence of Se of lower oxidation states (e.g., Se(IV) as selenite). While the abiotic control treatments (Ln, Hn) did not show a shift in oxidation state, treatments La and Ld show the clearest shift towards selenite and La also displayed a shift towards elemental Se at days 7 and 14. These results support the observations made during SEM and TEM analyses.

Figure 8. Normalized derivative spectra of Se obtained from X-ray absorption near edge structure (XANES) analysis. Spectra are grouped by treatment (La (light green), Ha (dark green), Ld (light blue), Hd (dark blue), Ln (pink), Hn (dark pink), $\mathrm{Se}^{\mathrm{VI}}$ standard (purple), $\mathrm{Se}^{\mathrm{IV}}$ standard (brown), $\mathrm{Se}^{0}$ standard (red)). For ease of comparison dashed lines indicate the position of the top of the peak of $\mathrm{Se}^{0}$ (red) and $\mathrm{Se}^{\mathrm{VI}}$ (purple). While the spectra are able to show a shift/appearance of a shoulder towards lower energies, it was not possible to quantify amounts of Se-species due to a limitation in sample amounts. The methods used are detailed in the methods section.
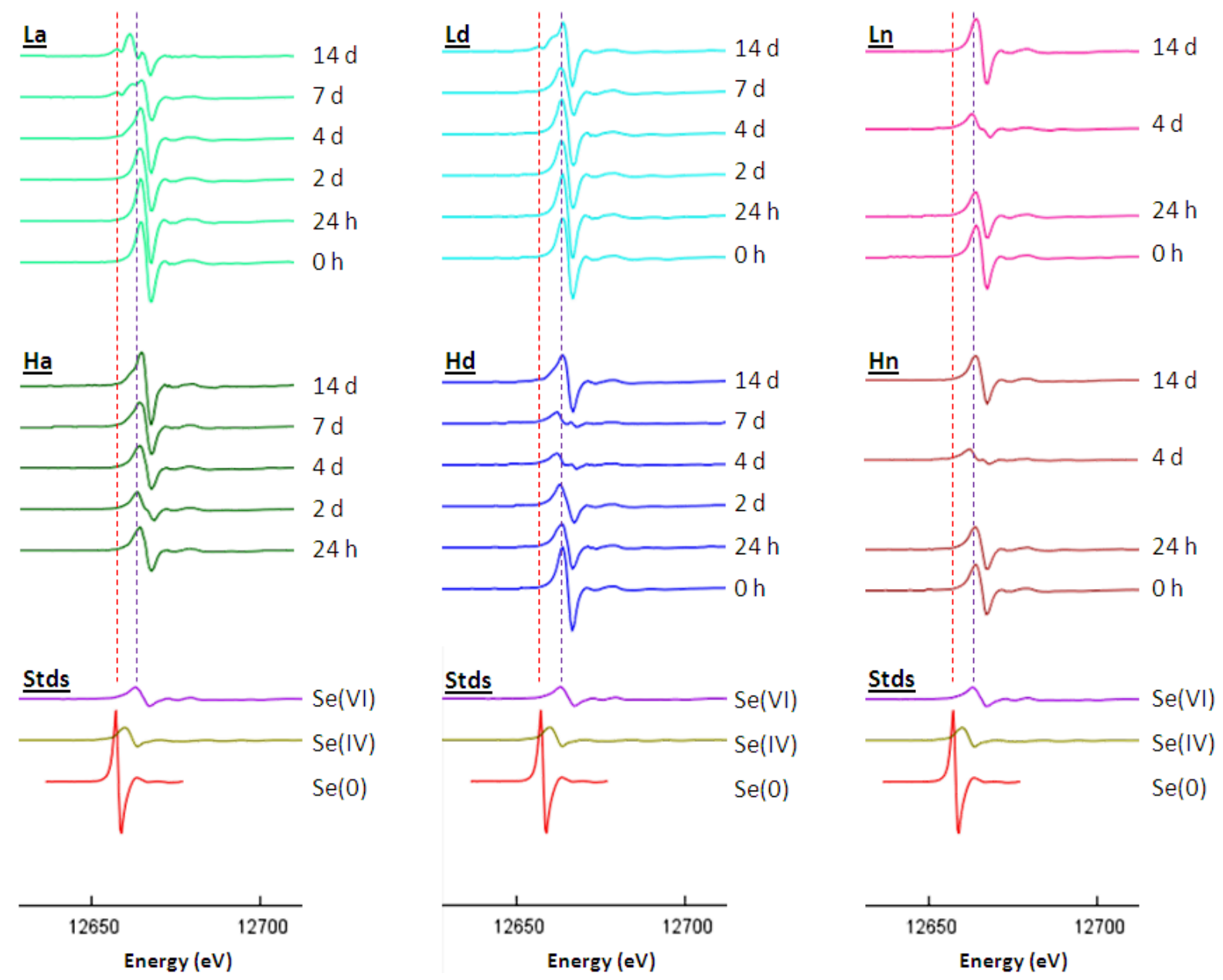

\section{Experimental Section}

\subsection{Jarosite Synthesis}

All solutions were prepared from American Chemical Society (ACS)-grade reagents and either filter sterilized $(0.2 \mu \mathrm{m})$ or autoclaved. Two jarosites with the generic formula $\mathrm{NaFe}_{3}\left(\mathrm{SO}_{4}\right)_{2}(\mathrm{OH})_{6}$ were 
synthesized, substituting $\mathrm{S}$ with $\mathrm{Se}$ at a high and low ratio [11]. The experimental stoichiometry for each jarosite was determined by acid digestion followed by ICP-OES ( $n=3$ for each jarosite), resulting in $\mathrm{Na}_{0.83}\left(\mathrm{H}_{3} \mathrm{O}\right)_{0.17} \mathrm{Fe}_{2.78}\left(\mathrm{SO}_{4}\right)_{1.26}\left(\mathrm{SeO}_{4}\right)_{0.74}(\mathrm{OH})_{5.33}\left(\mathrm{H}_{2} \mathrm{O}\right)_{0.67}$ for the low-dose Se-jarosite and $\mathrm{Na}_{0.92}\left(\mathrm{H}_{3} \mathrm{O}\right)_{0.008} \mathrm{Fe}_{3.06}\left(\mathrm{SeO}_{4}\right)_{2}(\mathrm{OH})_{6}$ for the high-dose Se-jarosite. The low-dose Se-jarosite was found to have a Se weight percent of $8.1 \%$, which equates to a $23.5 \%$ substitution of $\mathrm{S}$ by Se. The high-dose Se-jarosite had a Se weight percent of $30.1 \%$ equaling a $99.2 \%$ substitution of S by Se.

\subsection{Bacterial Culture}

A culture of Shewanella putrefaciens CN32 (ATC\# BAA-453) was prepared from $1.5 \mathrm{~mL}$ frozen glycerolized stock. The bacteria were pre-grown in sterile Trypticase Soy Broth (TSB) at $32{ }^{\circ} \mathrm{C}$ on a horizontal shaker at $120 \mathrm{rpm}$ for $24 \mathrm{~h}$. One $\mathrm{mL}$ of the pre-grown culture was transferred to $100 \mathrm{~mL}$ of TSB which was then incubated under the same conditions until bacterial growth reached late log phase $(18 \mathrm{~h})$. Bacteria were harvested by centrifugation at $5500 \mathrm{~g}$ for $10 \mathrm{~min}$ and washed with sterile $0.01 \mathrm{M}$ $\mathrm{NaNO}_{3}$ twice and once with $\mathrm{N}_{2}$ purged minimal media $\left(1.34 \mathrm{mM} \mathrm{KCl}, 28 \mathrm{mM} \mathrm{NH}_{4} \mathrm{Cl}, 0.68 \mathrm{mM} \mathrm{CaCl}_{2}\right.$, $50 \mathrm{mM} \mathrm{NaClO}_{4}, 24 \mathrm{mM} \mathrm{Na}$-lactate (60\% syrup), $20 \mathrm{mM}$ PIPES, adjusted to $\mathrm{pH} 7.4$ using $\mathrm{NaOH}$ ). The bacteria were inoculated in sterile $\mathrm{N}_{2}$ purged minimal media at an initial biomass concentration of 1.0 wet $\mathrm{g} / \mathrm{L}$. The inoculated medium with initial cell counts of $(6.7 \pm 0.3) \times 10^{5}$ cells $/ \mathrm{mL}$ was divided, and one portion was autoclaved to serve as a dead cell experimental control. Bacteria numbers and culture purity were determined via plating on trypticase soy agar.

\subsection{Setup and Sampling Procedure}

The minimal medium was transferred to an anaerobic chamber $\left(96 \% \mathrm{~N}_{2} ; 4 \% \mathrm{H}_{2}\right)$, and $10 \mathrm{~mL}$ aliquots were dispensed into $15 \mathrm{~mL}$ polypropylene test tubes containing $0.0500 \pm 0.0050 \mathrm{~g}$ of Se-jarosite. Six different sample treatments were prepared in total. Sample treatments were as follows: La $=23.5 \% \mathrm{Se}$, live bacteria; $\mathrm{Ld}=23.5 \% \mathrm{Se}$, dead bacteria; $\mathrm{Ln}=23.5 \% \mathrm{Se}$, no bacteria; $\mathrm{Ha}=99.2 \% \mathrm{Se}$, live bacteria; $\mathrm{Hd}=99.2 \% \mathrm{Se}$, dead bacteria; $\mathrm{Hn}=99.2 \% \mathrm{Se}$, no bacteria. With $\mathrm{L}=$ low Se substitution; $\mathrm{H}=$ high Se-substitution; $\mathrm{a}=$ minimal medium with living bacteria; $\mathrm{d}=$ minimal medium with dead, autoclaved bacteria, $\mathrm{n}=$ minimal medium only. All samples were prepared in triplicate, capped, sealed with parafilm, and placed on a benchtop rotator (Glas-Col) in an anaerobic chamber at room temperature and rotated in the dark end-over-end at $30 \mathrm{rpm}$. Destructive sampling in triplicate took place at 0, 3, 6, 9, 12 and $24 \mathrm{~h}$, spacing sampling points further apart after that to sampling at days 2, 4, 7, 10 and 14.

At each time interval, samples were monitored for Eh (Sure-Flow ${ }^{\circledR}$ combination redox/ORP electrode, Thermo Fisher Scientific, Waltham, MA, USA) and pH (Ross Sure-Flow semi-micro epoxy body $\mathrm{pH}$ probe, Thermo Fisher Scientific, Waltham, MA, USA). Viable bacterial numbers were determined at selected time intervals $(3 \mathrm{~h}, 9 \mathrm{~h}$, and days $2,4,7,10,14)$ by determination of colony forming units (CFU). For this, a subsample of $100 \mu \mathrm{L}$ was subjected to up to 8 serial $1 / 10$ dilutions in sterile isotonic $\mathrm{NaCl}$. One hundred $\mu \mathrm{L}$ from each of these dilutions was then spread onto trypticase soy agar (TSA) plates, and the plates were incubated in an inverted position for $48 \mathrm{~h}$ at $32{ }^{\circ} \mathrm{C}$. The number of colonies was counted for plates showing between 10 and 500 colonies, and the total number of CFU per sample was calculated as cells per mL. Microbial metabolism was monitored using the Promega BacTiter-Glo Microbial Cell Viability Assay measuring intra- and extracellular ATP [8]. Slurries from 
each sample were collected at selected time intervals and imaged using field emission-environmental scanning electron microscopy (FEESEM, FEI-Quanta 200F, FEI, Hillsboro, OR, USA) and transmission electron microscopy (TEM) $[8,10]$. Elemental analyses were performed in triplicate using the elemental X-ray spectroscopy (EDS) detector of the SEM. For TEM analysis, samples were preserved with $2.5 \%$ glutaraldehyde at a ratio of $1: 1(v / v)$ and prepared for analysis and analyzed using the same methods as in Smeaton et al. [8,11]. The remaining sample was filtered through a $0.2 \mu \mathrm{m}$ nylon filter. A subsample of $100 \mu \mathrm{L}$ was immediately analyzed for $\mathrm{Fe}(\mathrm{II})$ and total Fe concentrations using the Ferrozine method [37]. An additional subsample $(600 \mu \mathrm{L})$ was stored at $-20^{\circ} \mathrm{C}$ until analysis of Se oxyanion concentrations using high performance liquid chromatography coupled to atomic fluorescence spectrometry (HPLC-AFS). The remaining filtrate was acidified with doubly distilled $0.016 \mathrm{M} \mathrm{HNO}_{3}$ and stored at $4{ }^{\circ} \mathrm{C}$ until analysis for aqueous concentrations of $\mathrm{Fe}, \mathrm{Se}, \mathrm{S}$ and all minimal media components via inductively coupled plasma optical emission spectroscopy (ICP-OES).

X-ray absorption near edge structure spectroscopy (XANES) experiments was carried out at the Argonne National Laboratory (Argonne, IL, USA) at the PNC/XOR 20-BM-B beamline of the Advanced Photon Source. All sample material and reference solids were prepared in an oxygen-free environment and sealed between triple sided Kapton tape to minimize oxidation of Se. Adsorption spectra were collected at the Se K-edge $(12,658 \mathrm{eV})$ at room temperature in fluorescence mode using a solid state germanium detector. The energy of $\mathrm{Se}(0), \mathrm{Se}(\mathrm{IV})$ and $\mathrm{Se}(\mathrm{VI})$ was calibrated using a $\mathrm{Se}(0)$ foil as well as selenite and selenate standards between 7 layers of Kapton tape. Each sample was scanned 5 times. Data reduction and analysis were performed using the program ATHENA [48]. All results are presented with the standard error shown $(n=3)$.

\section{Conclusions}

Results of this investigation demonstrate that the presence of bacteria can have dramatic effects on Se-jarosite dissolution. The magnitude and end-product of this dissolution depends on both the level of solid phase Se substitution for S and the potential for Se toxicity to suppress bacterial activity. In the presence of live bacteria, Se jarosite dissolution is driven by biological activity, through both metabolic and non-metabolic pathways. These pathways include the intracellular metabolic reduction

of selenate to $\mathrm{Se}^{0}$, and possibly selenate adsorption onto cell surfaces by dead cells which was not investigated in this study but has been observed previously [39]. Jarosite containing a higher concentration of Se should be more structurally unstable resulting in distortions of the structural tetrahedral sites creating weakness in the crystallographic structure [40]. However, jarosites with both high and low Se showed similar concentrations of aqueous Se relative to the concentration of Se in each jarosite. The hypothesis that strain effects based on $100 \%$ substitution for the $\mathrm{T}$ site would facilitate increased microbial dissolution could not be confirmed. In both treatments containing live bacteria, CFU counts decreased from $1 \times 10^{6}$ to $1.5 \times 10^{3}$ and ATP values dropped to background levels (data not shown) over the experimental period. However, no significant difference in cell number or activity could be detected between treatments $\mathrm{La}$ and $\mathrm{Ha}$, and the differences in jarosite dissolution is therefore most likely due to a decrease in bacterial activity and/or a change of activity toward processes that counteract the toxic effects of the selenium, rather than gaining energy from the jarosite. The effectiveness of Shewanella putrefaciens CN-32 at removing Se from aqueous solution 
could be further assessed through the use of multiple concentrations of bacteria in solution, as more biomass may lead to more Se removal. This might be achieved via the use of a different growth medium that actively promotes bacterial growth rather than just sustaining the present community. This approach might also shed light on the question of whether high Se concentrations cause bacterial activity to shift from "growth-processes" to "detoxification processes" which could be investigated by looking at specific microbial activity via gene expression analyses to investigate changes in metabolic activity related to toxicity from high Se concentrations. The observed Se-jarosite dissolution in the presence of dead bacterial cells is attributed to the presence of lysed organic material reacting with the jarosite [49].

\section{Acknowledgments}

This research was supported by the Canadian Foundation for Innovation and the Ontario Innovation Trust (Christopher Weisener) and NSERC (Christopher Weisener). We like to thank Nick Falk, Zach Diloreto and Candace McCort who contributed to sample collection and analysis during the experiments, Sharon Lackie for ESEM analyses and Jean Claude Barrette for help with the ICP-OES analyses. We thank Marcia Reid at the University of McMaster for preparing the microtome samples for HRTEM analyses and Andreas Korniak for his assistance during HRTEM sample imaging and analysis. We thank Phillippe van Cappellen, Raoul Marie Couture, and Xu Zhang at the University of Waterloo for their assistance with HPLC-AFS and Christina Smeaton for constructive input during sample collection and review of the manuscript. The XAFS experiments were performed at the Pacific Northwest Consortium-Collaborative Access Team's (PNC/XOR) beamline at the Advanced Photon Source (APS) at the Argonne facility with help from Robert Gordon. Research at the PNC/XOR beamline, Advanced Photon Source, Argonne National Laboratory is supported by the Natural Sciences and Engineering Research Council of Canada through a major facilities access grant and the U.S. Department of Energy under contracts W-31-109-Eng-38 (APS) and DE-FG03-97ER45628 (PNC-CAT).

\section{Conflicts of Interest}

The authors declare no conflict of interest.

\section{References}

1. Manceau, A.; Tamura, N.; Marcus, M.A.; Alastair, A.M.; Celestre, R.S.; Sublett, R.E.; Sposito, G.; Padmore, H.A. Deciphering Ni sequestration in soil ferromanganese nodules by combining X-ray fluorescence, absorption, and diffraction at micrometer scales of resolution. Am. Mineral. 2002, 87, 1494-1499.

2. Strawn, D.; Doner, H.; Zavarin, M.; McHugo, S. Microscale investigation into the geochemistry of arsenic, selenium, and iron in soil developed in pyritic shale materials. Geoderma 2002, 108, $237-257$.

3. Tamaki, S.; Frankenberger, W.T., Jr. Environmental biochemistry of arsenic. Rev. Environ. Contam. Toxicol. 1992, 124, 79-110. 
4. Fanning, D.S.; Fanning, M.C.B. Soil: Morphology, Genesis and Classification; John Wiley \& Sons: Hoboken, NJ, USA, 1989; p. 395.

5. Evangelou, V.P.; Zhang, Y.L. A review: Poxidation mechanisms and acid mine drainage prevention. Crit. Rev. Environ. Sci. Technol. 1995, 25, 141-199.

6. Jambor, J.L. Nomenclature of the alunite supergroup. Can. Mineral. 1999, 37, 1323-1341.

7. Smeaton, C.M.; Fryer, B.J.; Weisener, C.G. Intracellular precipitation of $\mathrm{Pb}$ by Shewanella putrefaciens $\mathrm{CN} 32$ during the reductive dissolution of Pb-jarosite. Environ. Sci. Technol. Lett. 2009, 43, 8086-8091.

8. Smeaton, C.M.; Walshe, G.E.; Fryer, B.J.; Weisener, C.G. Reductive dissolution of Tl(I)-jarosite by Shewanella putrefaciens: Providing new insights into $\mathrm{Tl}$ biogeochemistry. Environ. Sci. Technol. Lett. 2012, 46, 11086-11094.

9. Dutrizac, J.E.; Jambor, J.L. Jarosites and their application in hydrometallurgy. Rev. Mineral. Geochem. 2000, 40, 405-452.

10. Smeaton, C.M.; Walshe, G.E.; Smith, A.M.L.; Hudson-Edwards, K.A.; Dubbin, W.E.; Wright, K.; Beale, A.M.; Fryer, B.J.; Weisener, C.G. Simultaneous release of Fe and As during the reductive dissolution of $\mathrm{Pb}$-As jarosite by Shewanella putrefaciens CN32. Environ. Sci. Technol. Lett. 2012, 46, 12823-12831.

11. Dutrizac, J.E.; Dinardo, O.; Kaiman, S. Selenate analogs of jarosite-type compounds. Hydrometallurgy 1981, 6, 327-337.

12. Nesbitt, H.W.; Muir, I.J.; Pratt, A.R. Oxidation of arsenopyrite by air and air-saturated, distilled water, and implications for mechanism of oxidation. Geochim. Cosmochim. Acta 1995, 59, 1773-1786.

13. Foster, A.L.; Brown, G.E., Jr.; Tingle, T.N.; Parks, G.A. Quantitative arsenic speciation in mine tailings using X-ray absorption spectroscopy. Am. Mineral. 1998, 83, 553-568.

14. Deverel, S.J.; Millard, S.P. Distribution and mobility of selenium and other trace elements in shallow groundwater of the western San Joaquin Valley, California. Environ. Sci. Technol. Lett. 1988, 22, 697-702.

15. Zhang, Y.Q.; Moore, J.N.; Frankenberger, W.T., Jr. Speciation of soluble selenium in agricultural drainage waters and aqueous soil-sediment extracts using hydride generation atomic absorption spectrometry. Environ. Sci. Technol. Lett. 1999, 33, 1652-1656.

16. Masscheleyn, P.H.; Delaune, R.D.; Patrick, W.H. Arsenic and selenium chemistry as affected by sediment redox potential and pH. J. Environ. Qual. 1991, 20, 522-527.

17. Chizhikov, D.M.; Ščastlivij, V.P. Selenium and Selenides; Collet's: Wellingborough, UK, 1968.

18. Frost, D.V.; Lish, P.M. Selenium in biology. Annu. Rev. Pharmacol. Toxicol. 1975, 15, 259-284.

19. Flohe, L.; Günzler, W.A.; Schock, H.H. Glutathione peroxidase: A selenoenzyme. FEBS Lett. 1973, 32, 132-134.

20. Johansson, L.; Gafvelin, G.; Arnér, E.S.J. Selenocysteine in proteins-Properties and biotechnological use. Biochim. Biophys. Acta 2005, 1726, 1-13.

21. Brown, T.A.; Shrift, A. Selenium: Toxicity and tolerance in higher plants. Biol. Rev. 1982, 57, 59-84.

22. Letavayová, L.; Vlcková, V.; Brozmanová, J. Selenium: From cancer prevention to DNA damage. Toxicology 2006, 227, 1-14. 
23. Winkel, L.H.E.; Johnson, C.A.; Lenz, M.; Grundl, T.; Leupin, O.X.; Amini, M.; Charlet, L. Environmental selenium research: From microscopic processes to global understanding. Environ. Sci. Technol. Lett. 2012, 46, 571-579.

24. Barceloux, D.G. Selenium. J. Toxicol. Clin. Toxicol. 1999, 37, 145-172.

25. Hockin, S.L.; Gadd, G.M. Linked redox precipitation of sulfur and selenium under anaerobic conditions by sulfate-reducing bacterial biofilms. Appl. Environ. Microbiol. 2003, 69, 7063-7072.

26. Stolz, J.F.; Oremland, R.S. Bacterial respiration of arsenic and selenium. FEMS Microbiol. Rev. 1999, 23, 615-627.

27. Tomei, F.A.; Barton, L.L.; Lemanski, C.L.; Zocco, T.G.; Fink, N.H.; Sillerud, L.O. Transformation of selenate and selenite to elemental selenium by Desulfovibrio desulfuricans. J. Ind. Microbiol. 1995, 14, 329-336.

28. Frankenberger, W.T., Jr.; Arshad, M. Bioremediation of selenium-contaminated sediments and water. Biofactors 2001, 14, 241-254.

29. Kashiwa, M.; Nishimoto, S.; Takahashi, K.; Ike, M.; Fujita, M. Factors affecting soluble selenium removal by a selenate-reducing bacterium Bacillus sp. SF-1. J. Biosci. Bioeng. 2000, 89, 528-533.

30. Kessi, J.; Ramuz, M.; Wehrli, E.; Spycher, M.; Bachofen, R. Reduction of selenite and detoxification of elemental selenium by the phototrophic bacterium Rhodospirillum rubrum. Appl. Environ. Microbiol. 1999, 65, 4734-4740.

31. Klonowska, A.; Heulin, T.; Vermeglio, A. Selenite and tellurite reduction by Shewanella oneidensis. Appl. Environ. Microbiol. 2005, 71, 5607-5609.

32. Macy, J.M.; Lawson, S.; Demoll-Decker, H. Bioremediation of selenium oxyanions in San Jaoquin drainage water using Thauera selenatis in a biological reactor system. Appl. Microbiol. Biotechnol. 1993, 40, 588-594.

33. Oremland, R.S.; Blum, J.S.; Bindi, A.B.; Dowdle, P.R.; Herbel, M.; Stolz, J.F. Simultaneous reduction of nitrate and selenate by cell suspensions of selenium-respiring bacteria. Appl. Environ. Microbiol. 1999, 65, 4385-4392.

34. Schmidt, R.; Tantoyotai, P.; Fakra, S.C.; Marcus, M.A.; Yang, S.I.; Pickering, I.J.; Bañuelos, G.S.; Hristova, K.R.; Freeman, J.L. Selenium biotransformations in an engineered aquatic ecosystem for bioremediation of agricultural wastewater via brine shrimp production. Environ. Sci. Technol. Lett. 2013, 47, 5057-5065.

35. Smith, A.M.L.; Hudson-Edwards, K.A.; Dubbin, W.E.; Wright, K. Dissolution of jarosite $\left[\mathrm{KFe}_{3}\left(\mathrm{SO}_{4}\right)_{2}(\mathrm{OH})_{6}\right]$ at $\mathrm{pH} 2$ and 8: Insights from batch experiments and computational modelling. Geochim. Cosmochim. Acta 2006, 70, 608-621.

36. Smith, A.M.L.; Dubbin, W.E.; Wright, K.; Hudson-Edwards, K.A. Dissolution of lead- and lead-arsenic-jarosites at $\mathrm{pH} 2$ and 8 and $20^{\circ} \mathrm{C}$ : Insights from batch experiments. Chem. Geol. 2006, 229, 344-361.

37. Viollier, E.; Inglett, P.W.; Hunter, K.; Roychoudhury, A.N.; Van Cappellen, P. The ferrozine method revisited: $\mathrm{Fe}(\mathrm{II}) / \mathrm{Fe}(\mathrm{III})$ determination in natural waters. Appl. Geochem. 2000, 15, 785-790.

38. Stookey, L.L. Ferrozine-A new spectrophotometric reagent for iron. Anal. Chem. 1970, 42, 779-781. 
39. Kenward, P.A.; Fowle, D.A.; Yee, N. Microbial selenate sorption and reduction in nutrient limited systems. Environ. Sci. Technol. Lett. 2006, 40, 3782-3786.

40. Paktunc, D.; Dutrizac, J.E. Characterization of arsenate-for-sulfate substitution in synthetic jarosite using X-ray diffraction and X-ray absorption spectroscopy. Can. Mineral. 2003, 41, 905-919.

41. Stolz, J.F.; Basu, P.; Santini, J.M.; Oremland, R.S. Arsenic and selenium in microbial metabolism. Annu. Rev. Microbiol. 2006, 60, 107-130.

42. Oremland, R.S.; Herbel, M.J.; Blum, J.S.; Langley, S.; Beveridge, T.J.; Ajayan, P.M.; Sutto, T.; Ellis, A.V.; Curran, S. Structural and spectral features of selenium nanospheres produced by Se-respiring bacteria. Appl. Environ. Microbiol. 2004, 70, 52-60.

43. Zehr, J.P.; Oremland, R.S. Reduction of selenate to selenide by sulfate-respiring bacteria: Experiments with cell suspensions and estuarine sediments. Appl. Environ. Microbiol. 1987, 53, 1365-1369.

44. Tomei, F.A.; Barton, L.L.; Lemanski, C.L.; Zocco, T.G. Reduction of selenate and selenite to elemental selenium by Wolinella succinogenes. Can. J. Microbiol. 1992, 38, 1328-1333.

45. Silverberg, B.A.; Wong, P.T.S.; Chau, Y.K. Localization of selenium in bacterial cells using TEM and energy dispersive X-ray analysis. Arch. Microbiol. 1976, 107, 1-6.

46. Losi, M.E.; Frankenberger, W.T. Reduction of selenium oxyanions by Enterobacter cloacae SLD1a-1: Isolation and growth of the bacterium and its expulsion of selenium particles. Appl. Environ. Microbiol. 1997, 63, 3079-3084.

47. Dungan, R.S.; Yates, S.R.; Frankenberger, W.T., Jr. Transformations of selenate and selenite by Stenotrophomonas maltophilia isolated from a seleniferous agricultural drainage pond sediment. Environ. Microbiol. 2003, 5, 287-295.

48. Ravel, B.; Newville, M. ATHENA, ARTEMIS, HEPHAESTUS: Data analysis for X-ray absorption spectroscopy using IFEFFIT. J. Synchrotron Radiat. 2005, 12, 537-541.

49. Bridge, T.A.M.; Johnson, D.B. Reductive dissolution of ferric iron minerals by Acidiphilium SJH. Geomicrobiol. J. 2000, 17, 193-206.

(C) 2014 by the authors; licensee MDPI, Basel, Switzerland. This article is an open access article distributed under the terms and conditions of the Creative Commons Attribution license (http://creativecommons.org/licenses/by/3.0/). 